\title{
Critical insight on the recent scenario of degraded lands in India and its bioremediation status
}

\author{
sharda dhadse ${ }^{1}$, Purushottam Sakhare ${ }^{2}$, G.H.V.C. Chary ${ }^{2}$, Aniket Aglawe², M. Mallikarjun \\ Rao ${ }^{1}$, Keerthana V.R ${ }^{1}$, Farsana Nazrin V.B. ${ }^{1}$, and Rohini Raut ${ }^{1}$ \\ ${ }^{1}$ CSIR-NEERI \\ ${ }^{2} \mathrm{MoEFCC}$
}

June 8, 2021

\begin{abstract}
Abstract The planet earth is composed of one-fourth of the land with a total geographical area of India as $328.2 \mathrm{M}$ ha. Due to various reasons, $14.64 \%$ of the land resource falls under wastelands. Rapid industrialization, intensive agricultural practices, and unsustainable urbanization lead to the degradation of land resources. Most of the time, the biophysical composition of the soil determined its utilization and productivity rate. Some are highly productive on the other hand some are less or unproductive, India has roughly 328 million hectares of land area and the land utility pattern been $43.6 \%$ agricultural, $4.6 \%$ grazing lands, $12.2 \%$ marshlands, $10.7 \%$ woodlands, $8.4 \%$ desolate land, $5.3 \%$ municipal land. The continuous increase of the population leads to pressure for uptown land. The area under non-agricultural land is used for the roads, buildings, railways, industrial establishments. In this connection, non-agricultural land is increasing which is a major concern about land degradation. Based on the secondary data this review paper discussed the contaminated land in India, respective case studies, and its remediation technologies. Many physical, chemical, and biological methods were adopted for cleaning the contaminated lands in them some are tough and some are expensive to handle.
\end{abstract}

\section{Hosted file}

Manuscript LDD.docx available at https://authorea.com/users/418628/articles/525313-criticalinsight-on-the-recent-scenario-of-degraded-lands-in-india-and-its-bioremediation-status

\section{Hosted file}

Land 8 Fig sub 2 final copy.docx available at https://authorea.com/users/418628/articles/ 525313-critical-insight-on-the-recent-scenario-of-degraded-lands-in-india-and-itsbioremediation-status 